\title{
Necrotizing Enterocolitis in Preterm Pigs Is Associated with Increased Density of Intestinal Mucosa-Associated Bacteria Including Clostridium perfringens
}

Støy, Ann Cathrine Findal; Mølbak, Lars; Delègue, Camilla Lindholm; Thymann, Thomas; Sangild, Per T.; Heegaard, Peter M. H.; Manurung, Sarmauli; Skovgaard, Kerstin

\section{Published in:}

Neonatology

Link to article, DOI:

$10.1159 / 000431280$

Publication date:

2015

Document Version

Peer reviewed version

Link back to DTU Orbit

Citation $(A P A)$ :

Støy, A. C. F., Mølbak, L., Delègue, C. L., Thymann, T., Sangild, P. T., Heegaard, P. M. H., Manurung, S., \& Skovgaard, K. (2015). Necrotizing Enterocolitis in Preterm Pigs Is Associated with Increased Density of Intestinal Mucosa-Associated Bacteria Including Clostridium perfringens. Neonatology, 108(3), 188-195.

https://doi.org/10.1159/000431280

\section{General rights}

Copyright and moral rights for the publications made accessible in the public portal are retained by the authors and/or other copyright owners and it is a condition of accessing publications that users recognise and abide by the legal requirements associated with these rights.

- Users may download and print one copy of any publication from the public portal for the purpose of private study or research.

- You may not further distribute the material or use it for any profit-making activity or commercial gain

- You may freely distribute the URL identifying the publication in the public portal 
1 Necrotizing enterocolitis in preterm pigs is associated with increased density of

2 intestinal mucosa-associated bacteria including $C$. perfringens

3

4

5

6

8

9

0

Short title: Tissue-associated bacteria and NEC

Ann Cathrine F. Støy ${ }^{1,2}$, Lars Mølbak ${ }^{1,3}$, Camilla L. Delègue ${ }^{2}$, Thomas Thymann ${ }^{2}$, Per T. Sangild ${ }^{2}$, Peter M. H. Heegaard ${ }^{1}$, Sarmauli Manurung ${ }^{1}$, Kerstin Skovgaard ${ }^{1 *}$

${ }^{1}$ National Veterinary Institute, Technical University of Denmark, DK-1870 Frederiksberg C, Denmark; ${ }^{2}$ Departments of Nutrition, Exercise and Sports/Clinical Veterinary and Animal Sciences, University of Copenhagen, DK-1958 Frederiksberg C, Denmark; ${ }^{3}$ Present address: Chr. Hansen, Bøge Allé 10, DK-2970 Hørsholm, Denmark

*Corresponding author: Kerstin Skovgaard, Innate Immunology Group, National Veterinary Institute, Technical University of Denmark, Bülowsvej 27, DK-1870 Frederiksberg C, Denmark, Phone: +45 35886362, Fax: +45 35886001, E-mail: kesk@vet.dtu.dk.

Key words: Animal model, Cell culture, Gene expression, Necrotizing enterocolitis, Microbiota, Quantitative PCR, Clostridium perfringens

1 Abbreviations: NEC, necrotizing enterocolitis; FISH, fluorescence in situ hybridization; PBS, phosphate buffered saline; MOI, multiplicity of infection; SEM, standard error of mean; RIN, RNA integrity number 


\section{Abstract}

Background: Necrotizing enterocolitis (NEC) is associated with changes in the luminal gut microbiota. It is not known whether the mucosa-associated microbiota is affected by NEC and stimulates inflammatory lesions. Objective: We hypothesized that the density of the mucosaassociated microbiota correlates with NEC severity in preterm pigs and that $C$. perfringens, which has been associated with NEC in preterm infants, is stimulating the expression of immune genes in intestinal epithelial cells. Methods: First, we determined the density of total bacteria and $C$. perfringens in the distal small intestinal mucosa of 58 NEC- and healthy preterm pigs using quantitative PCR. Next, we analyzed in IPEC-J2 cells the effect of different infection densities of $C$. perfringens type $\mathrm{A}$ on the expression of genes related to intestinal function and immune response. Results: Total bacterial and C. perfringens densities were higher in NEC- versus healthy pigs, and correlated positively with NEC severity. In IPEC-J2 cells expression levels of immune-related genes (CCL5, NFKBIA, IL8, IL1RN, and TNFAIP3) increased, while the expression of the sodium/glucose co-transporter (SLC5A1) decreased, with increasing density of C. perfringens. Conclusions: The density of mucosa-associated bacteria, and specifically C. perfringens, may stimulate the progression of NEC in preterm pigs. C. perfringens affects newborn porcine intestinal epithelial cells by changing their immune gene expression patterns, which may enhance the inflammation and development of lesions in the immature intestine.

\section{Introduction}

An unbalanced intestinal microbiota is a risk factor for necrotizing enterocolitis (NEC), but its exact contribution remains unclear. In general, studies show that infants developing NEC have a different gut microbiota than infants staying healthy [1]. Differences include lower bacterial diversity, higher density of total bacteria and increased numbers of Proteobacteria like E. coli and Klebsiella [2-5], 
but also of Clostridium spp. including C. perfringens [6,7; ?ny kilde/Sim et al 2015?], which may lead to a more severe and often lethal disease progression than other NEC-related pathogens [7;schlapbach?]. Thus, pathogens may at a certain threshold alone or together with other members of the microbiota stimulate NEC development. Still, in other studies only minimal changes are observed $[8,9]$. Therefore, cause and effect are difficult to separate.

The majority of intestinal microbiota analyses have relied on fecal samples to reflect the intestinal microbiota, and only few studies have included intestinal tissue or contents $[3,7,8]$. This may add further to the ambiguity regarding the composition of the microbiota due to differences in sample material [10]. The bacteria that are most relevant to NEC and directly affects intestinal epithelial cells may be those in close contact with the intestinal epithelial cells, the mucosa-associated microbiota. Access to intestinal samples from preterm infants is obviously difficult. Hence, the mucosa-associated microbiota is best investigated in appropriate animal models of NEC, coupled with cell studies. To provide novel insight into the association between NEC and the density of the mucosa-associated microbiota, and the transcriptional immune response of epithelial cells to $C$. perfringens, we used a preterm pig model of NEC [11] and a porcine intestinal IPEC-J2 cell line [12]. We hypothesized that NEC severity would correlate with the density of the distal small intestinal mucosa-associated bacteria. Although the etiology of NEC is multifactorial and several bacterial pathogens have been associated with the disease [2-7], we choose $C$. perfringens for more in-depth analysis. C. perfringens has repeatedly been associated with NEC in preterm pigs [reviewed in 13] and in preterm infants [6,7; ?ny kilde/Sim et al 2015?], where it often lead to a fulminant disease course [7; schlapbach?]. Furthermore, it is know to produce a large number of toxins and is a common cause of severe diseases including enteric disease in humans and animals [reviewed in Hatheway 1990]. (Thomas et al 1984?). The tissue samples originated from previous studies of diet-dependent differences in NEC-sensitivity and the mucosa-associated microbiota [14- 
16]. Therefore, the present study included 58 preterm pigs to investigate the association between the microbiota and NEC across diets. Furthermore, we investigated the effect of increasing numbers of C. perfringens on immune gene expression pattern in IPEC-J2 cells. This cell line is derived from the jejunum of a neonatal, unsuckled pig [12], and is a suitable in vitro model for newborn epithelial cells [17]. Our choice of genes was based on our previous diet studies in preterm pigs $[17,18]$ and studies on the effects of pathogens on IPEC-J2 cells [12].

\section{Materials and methods}

\section{Intestinal microbiota analyses}

Fifty-eight preterm pigs were delivered by caesarean section, and surgical procedures, rearing, diet intervention, euthanasia and tissue evaluation and collection have been described previously [1416]. The pigs were fed the following enteral diets: porcine colostrum $(n=5)$, formula $(n=9)$, formula + probiotics $(n=13)[14]$, formula containing lactose $(n=11)$ or maltodextrin $(n=11)$ as the principal carbohydrate source [15], or formula with a casein:whey-ratio of 60:40 (n = 9) [16]. Information on the composition of the diets can be found in table 1. After euthanasia, NEC was blinded evaluated in the stomach, proximal-, middle-, and distal small intestine, and colon using a score ranging from 1 (no or minimal focal hyperaemic gastroenterocolitis) to 6 (severe extensive hemorrhagic and necrotic gastroenterocolitis). A score of minimum three in one intestinal region was defined as a case of NEC. All animal protocols and procedures were approved by the Danish National Committee on Animal Experimentation.

To get an approximation of the mucosa-associated microbiota for both FISH and quantitative PCR, the luminal content was gently removed by squeezing along the length of the intestine and the remaining tissue used for analysis. To visualize the association between the microbiota and the intestinal tissue, fluorescence in situ hybridization (FISH) was performed on distal small intestinal 
samples without luminal content from two of the studies [15,16] as previously described [14]. Quantitative PCR was performed on distal small intestinal samples without luminal content that was collected as full thickness tissue samples of $3 \mathrm{~cm}$, snap frozen in liquid nitrogen and stored at $-80^{\circ} \mathrm{C}$ until analysis. DNA from the tissue samples was extracted using the QIAamp DNA mini kit (Qiagen, West Sussex, UK) according to the manufacturer's instructions. Quantification of total bacteria [19] and C. perfringens [20] was performed according to previous studies, but with minor modifications. Briefly, the reaction mixture $(25 \mu \mathrm{l})$ for total bacteria included 25 ng extracted DNA, 2× TaqMan Universal PCR Master Mix (Applied Biosystems, Nærum, Denmark), $0.9 \mu \mathrm{M}$ of each primer $(0.09 \mu \mathrm{M}$ of primer $8 \mathrm{FB})$ and $0.2 \mu \mathrm{M}$ TaqMan probe. For $C$. perfringens, $20 \mu \mathrm{l}$ reaction mixture included 20 ng extracted DNA, 2× Taqman Universal PCR Master Mix (Applied Biosystems), $0.25 \mathrm{mg} / \mathrm{ml}$ bovine serum albumin (Applied Biosystems), $1 \mu \mathrm{M}$ of each primer and $0.1 \mu \mathrm{M}$ TaqMan probe. Primers and probes (table 2) were synthesized at DNA Technology, Aarhus, Denmark. Quantitative PCR was performed on a RotorGene 3000 Detection System (Corbett Life Science, Sydney, Australia) under the following conditions: $95^{\circ} \mathrm{C}$ for $10 \mathrm{~min}$, followed by 40 cycles at $95^{\circ} \mathrm{C}$ for $30 \mathrm{~s}, 55^{\circ} \mathrm{C}$ for $30 \mathrm{~s}, 60^{\circ} \mathrm{C}$ for $45 \mathrm{~s}, 65^{\circ} \mathrm{C}$ for $15 \mathrm{~s}$, and $72^{\circ} \mathrm{C}$ for $15 \mathrm{~s}$ for total bacteria, and $95^{\circ} \mathrm{C}$ for $10 \mathrm{~min}, 45$ cycles at $94^{\circ} \mathrm{C}$ for $10 \mathrm{~s}, 55^{\circ} \mathrm{C}$ for $20 \mathrm{~s}$, and $70^{\circ} \mathrm{C}$ for $10 \mathrm{~s}$ for $\mathrm{C}$. perfringens. Standard curves were generated using C. perfringens DNA (NCTC 10240, National Veterinary Institute, Frederiksberg C, Denmark) ranging over five (total bacteria) and six (C. perfringens) tenfold dilutions from the limit of detection (total bacteria, $0.1 \mathrm{pg} \mathrm{DNA} / \mu \mathrm{l}$ and $C$. perfringens, $0.0125 \mathrm{pg} \mathrm{DNA} / \mu \mathrm{l})$. Cycle threshold was determined using the Rotor-Gene 3000 data analysis software (Corbett Life Science) using the Auto-Find Threshold function. Standards and samples were run in triplicates, and every reaction plate included one non-template control in triplicate. Due to lack of sample material, samples from 49 pigs were included in the total bacteria assay, while samples from all 58 pigs were included in the $C$. perfringens assay. The results were 
121 calculated as relative quantities measured as pg DNA/25 ng of extracted total DNA (total bacteria) 122 and pg DNA/20 ng of extracted total DNA (C. perfringens).

\section{Gene expression in IPEC-J2 cells during C. perfringens infection}

IPEC-J2 cells [12] were maintained as previously described [17]. C. perfringens type A (NCTC 10240, National Veterinary Institute) was cultured $\left(16 \mathrm{~h} ; 37^{\circ} \mathrm{C}\right.$; anaerobic; brain heart infusion broth, SSI diagnostics, Hillerød, Denmark), washed twice in Dulbecco’s phosphate buffered saline (PBS, Sigma-Aldrich, Brøndby, Denmark) and resuspended in growth medium that was prepared according to [17], but without antibiotics. For the experiment, IPEC-J2 cells were grown in 6-well plates (Corning Costar cell culture plates, Sigma-Aldrich) until near-confluence was achieved and incubated in growth medium without antibiotics for $24 \mathrm{~h}$. They were infected for $2 \mathrm{~h}$ with $C$. perfringens at multiplicity of infection $(\mathrm{MOI} ; \mathrm{n}=5)=0,10,20$ and 50 determined by OD600 measurement. Hereafter, the supernatant was collected, and the cells washed (PBS) and harvested (1× trypsin:EDTA, Sigma-Aldrich). The cells and supernatant were centrifuged (10 min; 1000 rpm; $4^{\circ} \mathrm{C}$ ), and the cell pellet stored at $-80^{\circ} \mathrm{C}$. The gene expression analysis was done as previously described using reverse transcription quantitative real-time PCR [17,21]. Genes are denoted by their gene symbol and information on primers for reference genes and genes showing significant differences can be found in table 3, while information on the 48 primer pairs analyzed have been published previously [17]. RPL13A and ACTB were the most stably expressed reference genes of 5 candidate genes, and used to normalize all samples in GenEx5 (MultiD Analyses AB, Göteborg, Sweden). After normalization, quantification cycle was converted to relative quantities. Relative expression of the sample with the lowest level of expression was scaled to 1 for each primer assay.

\section{Statistical analyses}


145 The density of total bacteria and C. perfringens was analyzed using a Mann-Whitney test with a 146 Dunn's multiple comparison post-hoc test in GraphPad Prism (Version 5.02, La Jolla, CA, USA) 147 and the results considered significant when $\mathrm{p}<0.05$. Correlation analysis was performed using 148 Spearman correlation analysis in GraphPad Prism, and correlations were considered significant if $\rho$ $149<-0.5 />0.5$, equal to $\mathrm{p}<0.001$. Analysis of the gene expression in IPEC-J2 cells was performed as 150 previously described [17]. Data was $\log _{2}$ transformed and tested with a one-way ANOVA with a 151 Tukey-Kramer’s post-hoc test (GenEx5, MultiD Analyses AB). Gene expression was considered significant if $\mathrm{p}<0.05$ and relative gene expression differences were $>2.0$-fold between the groups.

\section{Results}

\section{Intestinal microbiota analyses}

Visual inspection of FISH images showed a higher number of bacterial micro-colonies associated with the mucosa in NEC- than healthy pigs. C. perfringens was part of the micro-colonies, which were found along the length of the villi and down to the crypts in NEC- and healthy pigs. Quantitatively, total bacterial density was higher in NEC- $(n=34)$ compared with healthy pigs $(n=$ 15), and the same was observed for the density of C. perfringens when comparing NEC- $(n=38)$

161 with healthy pigs $(n=20$, figure $1 A, B)$. The correlation between the density of total bacteria and 162 the distal small intestinal NEC score was $\rho=0.440, \mathrm{p}<0.01$ (figure $1 \mathrm{C}$ ) mainly driven by the low 163 NEC score pigs. An even more positive correlation was found between the distal small intestinal 164 NEC score and the density of $C$. perfringens ( $\rho=0.687, \mathrm{p}<0.001$, figure 1D). Finally, a positive correlation between the densities of total bacteria and C. perfringens was observed $(\rho=0.585, \mathrm{p}<$ 0.001). 
The in vitro experiment showed that the cellular response of IPEC-J2 cells changed with increasing number of $C$. perfringens type A. A small effect was observed on the RNA integrity, measured by RNA integrity number $(\mathrm{RIN})$, as this decreased from MOI $=0$ (mean RIN $=9.98 \pm 0.02)$ to $\mathrm{MOI}=$ 20 (mean RIN $=9.38 \pm 0.25)$. The largest effect was seen at MOI $=50$ since a RIN for only one replicate was obtainable, which indicated a high degree of RNA degradation resulting from cell lysis (figure 2A). To assure the most accurate results, the $\mathrm{MOI}=50$ group and one $\mathrm{MOI}=10$ replicate were excluded in the statistical analysis as large differences in RIN may affect the results. Of the 22 genes, passing the data evaluation (table 3), six were differentially expressed between the MOI groups (figure 2B). The expression of CCL5, NFKBIA, IL8 and TNFAIP3, encoding proteins involved in inflammation, was up-regulated in $\mathrm{MOI}=10$ compared with $\mathrm{MOI}=0$. Furthermore, NFKBIA and TNFAIP3 expression was higher at MOI $=20$ compared with $\mathrm{MOI}=0$. The expression of CCL5 and IL8 decreased at MOI = 20 to levels between $\mathrm{MOI}=0$ and $\mathrm{MOI}=10$, while the decrease in $I L 1 R N$ resulted in a difference between MOI $=10$ and MOI $=20$. The expression of SLC5A1 (sodium/glucose co-transporter) decreased with increasing MOI.

\section{Discussion}

In this study, we observed an association between NEC severity and the density of total bacteria, including $C$. perfringens Type $\mathrm{A}$, in the distal small intestinal mucosa of preterm pigs. The results indicate that the mucosal bacterial density is a factor associated with the progression of NEC. Even though this study does not clarify the exact contribution of the microbiota to the pathogenesis, we speculate that reaching a certain threshold of bacterial contact stresses the immature intestinal epithelium and set off the inflammatory process towards NEC. Although 14 of the 38 pigs with NEC did not have lesions in the distal small intestine, but in another intestinal region, the density of total bacteria in the distal small intestine was similar to pigs with NEC in this region (data not 
shown). We speculate that the increased density of bacteria in the distal small intestine might reflect the bacterial density in other regions of the intestine, and in the initial phase of NEC, another region was stressed before the distal small intestinal region and the inflammatory process towards NEC initiated here. The NEC-inducing effect of mucosal bacteria may interact with diet factors, because a high intake of poorly digestible milk diets would likely increase bacterial proliferation and metabolism. The results are in accordance with studies in preterm infants and pigs showing an association between NEC and the density of both total bacteria [3,4] and C. perfringens [6,7,13]. The association between specific bacteria and NEC lesions could be due to increased density of total bacteria, which was observed by the positive correlation between the density of total bacteria and C. perfringens. However, the induction of intestinal injury by specific pathogens may still be significant. Bjørnvad et al. [22] found that C. perfringens invaded the tissue more deeply in NECcompared with healthy pigs. In the present study, FISH observations showed bacteria closely associated with the surface of the intestinal epithelium, and invasive pathogens could therefore potentially affect the epithelial cells directly.

Gene expression changes in IPEC-J2 cells exposed to C. perfringens were observed by an increased expression of inflammatory factors concomitant with a decrease in SLC5A1. In contrast, other genes like CD14, IL6, IL18 and TLR4, involved in the innate immune response, were not affected. Genes encoding pro-inflammatory factors, IL8 and CCL5, and anti-inflammatory factors, IL1RN, NFKBIA and TNPAIP3, were affected by the increased numbers of $C$. perfringens, and indicate that increased bacterial level initiates an inflammatory response. A concomitant up-regulation of IL-8 and IL-10 in plasma was also observed in preterm infants in response to severe NEC [23]. Likewise, CCL5, IL8 and NFKBIA were up-regulated with increasing NEC in preterm pigs [24, unpublished data] generating further evidence for the applicability of IPEC-J2 cells as a low cost model for the neonatal intestine. In preterm pigs given oral antibiotics NEC is prevented and IL8 and other 
immune-related genes are down-regulated [25]. The decrease in SLC5A1 expression indicates that absorptive functions are compromised during $C$.

C. perfringens infection. This could cause accumulation of nutrients available for bacterial fermentation and lead to bacterial overgrowth and cytotoxic levels of metabolites. Conversely, providing milk diets that easily exceed the immature digestive capacity of preterm newborns may provide substrates for bacterial fermentation. In quails, excessive luminal fermentation by Clostridium species leads to NEC-like lesions [26]. Bacterial toxins may also have a cytotoxic effect, and a rapid up-regulation of toxins by C. perfringens type C when in close contact with Caco-2 cells was observed [27]. However, in preterm infants no positive correlation was found between C. perfringens $\alpha$-toxins and NEC severity [7]. Further studies should investigate if the observed changes in gene expression of the epithelial cells are unique to $C$. perfringens and if differences, for example production of metabolites, between pathogens involved in NEC are associated with different disease courses.

In conclusion, mucosa-associated bacterial density is associated with NEC severity in preterm pigs. Furthermore, specific pathogens may play a role in NEC development that was shown in this study by the association between NEC severity and the density of $C$. perfringens, and by the ability of this pathogen to induce changes in immune response genes of intestinal epithelial cells in vitro. It is highly likely, that increased bacterial density in close association with the intestinal epithelium also 234 plays an important role for NEC development in preterm infants, both in its initiation and progression to severe mucosal lesions. Our results suggest that preventive measures against NEC might be directed towards stimulating the mucosal barrier against bacterial attachment, coupled with provision of diets that minimize maldigestion and substrates available for fermentation. This could include stimulation of intestinal mucus production by highly digestible and immunemodulating milk diets [28] or by decreasing bacterial density using oral antibiotics [25], as shown in preterm pig studies. 


\section{References}

242 (1) Neu J: Necrotizing enterocolitis: The mystery goes on. Neonatology 2014;106:289-295.

243 (2) Wang Y, Hoenig JD, Malin KJ, Qamar S, Petrof EO, Sun J, Antonopoulos DA, Chang EB, Claud EC: 16S rRNA gene-based analysis of fecal microbiota from preterm infants with and without necrotizing enterocolitis. ISME J 2009;3:944-954.

(3) Bucher BT, McDuffie LA, Shaikh N, Tarr PI, Warner BB, Hamvas A, White FV, Erwin CR, Warner BW: Bacterial DNA content in the intestinal wall from infants with necrotizing

(4) Jenke AC, Postberg J, Mariel B, Hensel K, Foell

D, Dabritz J, Wirth S: S100A12 and hBD2 correlate with the composition of the fecal microflora in ELBW infants and expansion of E. coli is associated with NEC. Biomed Res Int 2013;2013:150372.

(5) Torrazza RM, Ukhanova M, Wang X, Sharma R, Hudak ML, Neu J, Mai V: Intestinal microbial ecology and environmental factors affecting necrotizing enterocolitis. PLoS One 2013;8:e83304.

(6) De La Cochetiere MF, Piloquet H, des Robert C, Darmaun D, Galmiche JP, Roze JC: Early intestinal bacterial colonization and necrotizing enterocolitis in premature infants: the putative role of Clostridium. Pediatr Res 2004;56:366-370. enterocolitis of the neonate with Clostridium perfringens: diagnosis, clinical course, and role of alpha toxin. Eur J Pediatr 2008;167:891-895.

261 (8) Smith B, Bodé S, Petersen BL, Jensen TK, Pipper C, Kloppenborg J, Boye M, Krogfelt KA, Mølbak L: Community analysis of bacteria colonizing intestinal tissue of neonates with necrotizing enterocolitis. BMC Microbiol 2011;11:73. 
264 (9) Normann E, Fahlen A, Engstrand L, Lilja HE: Intestinal microbial profiles in extremely preterm infants with and without necrotizing enterocolitis. Acta Paediatr 2013;102:129-136.

(10) Romano-Keeler J, Moore DJ, Wang C, Brucker RM, Fonnesbeck C, Slaughter JC, Li H,

(11) Sangild PT, Siggers RH, Schmidt M, Elnif J, Bjørnvad CR, Thymann T, Grondahl ML, Hansen AK, Jensen SK, Boye M, Mølbak L, Buddington RK, Weström BR, Holst JJ, Burrin enterocolitis in preterm pigs. Gastroenterology 2006;130:1776-1792.

(12) Schierack P, Nordhoff M, Pollmann M, Weyrauch KD, Amasheh S, Lodemann U, Jores J, Tachu B, Kleta S, Blikslager A, Tedin K, Wieler LH: Characterization of a porcine intestinal epithelial cell line for in vitro studies of microbial pathogenesis in swine. Histochem Cell Biol 2006;125:293-305.

(13) Cilieborg MS, Boye M, Sangild PT: Bacterial colonization and gut development in preterm neonates. Early Hum Dev 2012;88:S41-S49.

(14) Siggers RH, Siggers JL, Boye M, Thymann T, Mølbak L, Leser TD, Jensen BB, Sangild PT: Early administration of probiotics alters bacterial colonization and limits diet-induced gut dysfunction and severity of necrotizing enterocolitis in preterm pigs. J Nutr 2008;138:14371444.

(15) Thymann T, Møller HK, Stoll B, Støy ACF, Buddington RK, Bering SB, Jensen BB, Olutoye OO, Siggers RH, Mølbak L, Sangild PT, Burrin DG: Carbohydrate maldigestion induces necrotizing enterocolitis in preterm pigs. Am J Physiol Gastrointest Liver Physiol 2009;297:G1115-G1125. 
(16) Thymann T, Støy ACF, Bering SB, Mølbak L, Sangild PT: Casein addition to a whey-based formula has limited effects on gut function in preterm pigs. J Anim Sci 2012;90:378-380.

(17) Støy ACF, Heegaard PMH, Sangild PT, Østergaard MV, Skovgaard K: Gene Expression analysis of the IPEC-J2 cell line: A simple model for the inflammation-sensitive preterm intestine. ISRN Genomics 2013;2013:980651.

(18) Cilieborg MS, Skovgaard K, Nørgaard LM, Sangild PT, Boye M: Intestinal colonization, gut function and inflammatory responses are moderately influenced by gestational age at birth. Abstract from 14th International Symposium on Microbial Ecology 2012.

(19) Palmer C, Bik EM, Digiulio DB, Relman DA, Brown PO: Development of the human infant intestinal microbiota. PLoS Biol 2007;5:1556-1573.

(20) Wise MG, Siragusa GR: Quantitative detection of Clostridium perfringens in the broiler fowl gastrointestinal tract by real-time PCR. Appl Environ Microbiol 2005;71:3911-3916.

(21) Skovgaard K, Cirera S, Vasby D, Podolska A, Breum SØ, Dürrwald R, Schlegel M, Heegaard PMH: Expression of innate immune genes, proteins and microRNAs in lung tissue of pigs infected experimentally with influenza virus (H1N2). Innate Immun 2013;19:531-544.

(22) Bjørnvad CR, Thymann T, Deutz NE, Burrin DG, Jensen SK, Jensen BB, Mølbak L, Boye M, Larsson LI, Schmidt M, Michaelsen KF, Sangild PT: Enteral feeding induces diet-dependent mucosal dysfunction, bacterial proliferation, and necrotizing enterocolitis in preterm pigs on parenteral nutrition. Am J Physiol Gastrointest Liver Physiol 2008;295:G1092-G1103.

(23) Edelson MB, Bagwell CE, Rozycki HJ: Circulating pro- and counterinflammatory cytokine levels and severity in necrotizing enterocolitis. Pediatrics 1999;103:766-771.

(24) Støy ACF, Heegaard PMH, Thymann T, Bjerre M, Skovgaard K, Boye M, Stoll B, Schmidt M, Jensen BB, Sangild PT: Bovine colostrum improves intestinal function following formulainduced gut inflammation in preterm pigs. Clin Nutr 2014;33:322-329. 
(25) Jensen ML, Thymann T, Cilieborg MS, Lykke M, Mølbak L, Jensen BB, Schmidt M, Kelly D, Mulder I, Burrin DG, Sangild PT: Antibiotics modulate intestinal immunity and prevent necrotizing enterocolitis in preterm neonatal piglets. Am J Physiol Gastrointest Liver Physiol 2014;306:G59-G71.

(26) Waligora-Dupriet AJ, Dugay A, Auzeil N, Huerre M, Butel MJ: Evidence for clostridial

(27) Vidal JE, Ohtani K, Shimizu T, McClane BA: Contact with enterocyte-like Caco-2 cells induces rapid upregulation of toxin production by Clostridium perfringens type C isolates. Cell Microbiol 2009;11:1306-1328.

(28) Puiman PJ, Jensen M, Stoll B, Renes IB, de Bruijn AC, Dorst K, Schierbeek H, Schmidt M, Boehm G, Burrin DG, Sangild PT, van Goudoever JB: Intestinal threonine utilization for protein and mucin synthesis is decreased in formula-fed preterm pigs. J Nutr 2011;141:13061311.

(29) Amann RI, Binder BJ, Olson RJ, Chisholm SW, Devereux R, Stahl DA: Combination of 16S rRNA-targeted oligonucleotide probes with flow cytometry for analyzing mixed microbial populations. Appl Environ Microbiol 1990;56:1919-1925. 


\section{Figure legends}

338 Figure 1: (A) Association between NEC and the density of total bacteria and (B) the density of $C$. 339 perfringens in NEC- (NEC-pigs) and healthy pigs (HEAL-pigs) determined by quantitative PCR. 340 Significant differences are indicated as $*$ for $\mathrm{p}<0.05$ and $* * *$ for $\mathrm{p}<0.001$. Since two different 341 quantitative PCR assays have been used for quantification of total bacteria and C. perfringens figure 342 (A) and (B) cannot be directly compared. Spearman correlations between distal small intestinal 343 NEC score and the density of (C) total bacteria and (D) C. perfringens.

345 Figure 2: (A) RNA degradation in IPEC-J2 cells measured by the RNA integrity number (RIN) and 346 (B) relative fold changes (mean + standard error of mean) of genes significantly different expressed 347 in IPEC-J2 cells stimulated with C. perfringens at multiplicity of infection (MOI) $=0$ (white bars), 34810 (light grey bars) and 20 (black bars). Different superscript letters (a,b) indicate significant 349 differences, $\mathrm{p}<0.05$ and fold change $>2$. 


\section{Tables}

Table 1: Diet composition in macronutrient content pr litre. All diets were fed as a bolus $(15 \mathrm{ml} / \mathrm{kg}$ body weight) every $3 \mathrm{~h}$.

\begin{tabular}{|c|c|c|c|c|c|c|c|}
\hline \multirow[t]{2}{*}{ Diet } & \multirow[t]{2}{*}{ Energy, kJ } & \multicolumn{2}{|c|}{ Protein, g } & \multicolumn{3}{|c|}{ Carbohydrates, g } & \multirow[t]{2}{*}{ Fat, $g$} \\
\hline & & Whey & Casein & Maltodextrin & $\begin{array}{l}\text { Lactos } \\
\text { e }\end{array}$ & Other & \\
\hline \multicolumn{8}{|l|}{ Sow colostrum } \\
\hline Formula $^{\# \#}$ & 4151 & 67 & 0 & 45 & & 9 & 61 \\
\hline Formula with probiotics ${ }^{\# \#}$ & 4151 & 67 & 0 & 45 & & 9 & 61 \\
\hline Formula with lactose $\mathrm{F}^{\text {\#\# }}$ & 4648 & 63 & 0 & 8 & 48 & 2 & 70 \\
\hline $\begin{array}{l}\text { Formula } \\
\text { maltodextrin }^{\# \# \#}\end{array}$ & 4634 & 62 & 0 & 55 & 0 & 6 & 70 \\
\hline $\begin{array}{l}\text { Formula Casein:whey ratio } \\
\text { of } 60: 40^{\# \# \#}\end{array}$ & 4620 & 25 & 37 & 55 & 0 & 6 & 70 \\
\hline
\end{tabular}

\# Porcine colostrum was collected manually from sows (Large White x Landrace, Research Station Sjælland II, Denmark) within $6 \mathrm{~h}$ of completed farrowing and stored at $-20^{\circ} \mathrm{C}$ until used. Values for the composition of colostrum, see Sangild \& Xu, 2004. Sangild PT \& Xu RJ (2004) Colostrum. In Encyclopedia of Animal Science, pp. 1-3 [WG Pond and AW Bell, editors]. New York: Marcel Dekker.

\#\# Ingredients used: Pepdite, Maxipro and Liquigen-MCT, all products kindly donated by SHS International, Liverpool, UK. The probiotic mixture (kindly donated by Chr. Hansen, A/S) consisted of Bifidobacterium animalis (DSM15954) and 4 Lactobacillus species: acidophilus (DSM13241), casei (ATCC55544), pentosus (DSM14025), and plantarum (DSM13367). Probiotics were reconstituted in $1 \%$ peptone-water and each strain was included at $10^{9}$ colony-forming units (CFU)/g of viable lyophilized bacteria for a total concentration of $5 \times 10^{9} \mathrm{CFU} / 3 \mathrm{~mL}$ peptone-water. Boluses of probiotics or peptone-water placebo were administered ( $2 \mathrm{~mL} / \mathrm{kg} \mathrm{BW}$ ) every $6 \mathrm{~h}$ during the TPN period and every $3 \mathrm{~h}$ during the enteral phase. Boluses of probiotics were reconstituted fresh prior to every bolus administration.

\#\#\# Ingredients used: Seravit, Liquigen medium-chain triglyceride, and Calogen long-chain triglyceride (Nutricia, Allerød, Denmark); Variolac and Lacprodan alpha-15 and Miprodan (ARLA Foods Ingredient, Viby, Denmark); and Polycose (Abbott Nutrition, Columbus, OH). 
Table 2. Oligonucleotide sequences of primers and probes used for quantification PCR and visualization (fluorescence in situ hybridization) of total bacteria and C. perfringens in distal small intestinal tissue of preterm pigs.

\begin{tabular}{lll}
\hline Primer/probe name & Oligonucleotide sequence (5'-3') & Reference \\
\hline Quantitative PCR & & [19] \\
Total bacteria & & \\
Forward primers & 8FM: AGAGTTTGATCMTGGCTCAG & \\
& 8FB: AGGGTTCGATTCTGGCTCAG & [20] \\
Reverse primer & Bact515R: TTACCGCGGCKGCTGGCAC \\
TaqMan probe & Bact338K: [FAM]CCAKACTCCTACGGGAGGCAGCAG[TAMRA] \\
& \\
C. perfringens & CPerf165F: CGCATAACGTTGAAAGATGG \\
Forward primer & CPerf269R: CCTTGGTAGGCCGTTACCC & [11] \\
Reverse primer & CPerf187F: [FAM]TCATCATTCAACCAAAGGAGCAATCC[TAMRA] & \\
TaqMan probe & & \\
Fluorescence in situ hybridization & S-D-bact-0338-a-A-18: [FITC]GCTGCCTCCCGTAGGAGT \\
Total bacteria & S-Cl.perf-185-a-A-18: [Cy3]TGGTTGAATGATGATGCC \\
C. perfringens &
\end{tabular}


Table 3. Gene symbol, protein name, forward (F) and reverse (R) primer sequences, amplicon length and primer efficiency for reference genes and genes of interest in IPEC-J2 cells during C. perfringens infection.

\begin{tabular}{|c|c|c|c|c|}
\hline Gene symbol & Protein & Sequence $\left(5^{\prime}-3^{\prime}\right)$ & Amplicon length & Efficiency \\
\hline \multicolumn{5}{|l|}{ Reference genes } \\
\hline \multirow[t]{2}{*}{$A C T B$} & $\beta$-actin & F: CTACGTCGCCCTGGACTTC & 76 & 0.93 \\
\hline & & R: GCAGCTCGTAGCTCTTCTCC & & \\
\hline \multirow[t]{2}{*}{ RPL13A } & Ribosomal protein L13a & F: ATTGTGGCCAAGCAGGTACT & 76 & 0.85 \\
\hline & & R: AATTGCCAGAAATGTTGATGC & & \\
\hline \multicolumn{5}{|c|}{ Genes of interest showing significant difference between groups } \\
\hline \multirow[t]{2}{*}{ CCL5 } & Chemokine (C-C motif) ligand 5 & F: CTCCATGGCAGCAGTCGT & 121 & 0.92 \\
\hline & & R: AAGGCTTCСТCСАТССТAGC & & \\
\hline \multirow[t]{2}{*}{$I L 1 R N$} & Interleukin 1 receptor antagonist & F: TGCCTGTCCTGTGTCAAGTC & 90 & 0.98 \\
\hline & & R: GTCCTGCTCGCTGTTCTTTC & & \\
\hline \multirow[t]{2}{*}{ IL8 } & Interleukin 8 & F: TTGCCAGAGAAATCACAGGA & 78 & 0.80 \\
\hline & & R: TGCATGGGACACTGGAAATA & & \\
\hline \multirow[t]{2}{*}{ NFKBIA } & Nuclear factor of kappa light polypeptide & F: GAGGATGAGCTGCCCTATGAC & 85 & 0.88 \\
\hline & gene enhancer in B-cells inhibitor, alpha & R: CCATGGTCTTTTAGACACTTTCC & & \\
\hline \multirow[t]{2}{*}{ SLC5A1 } & Sodium/glucose co-transporter & F: CTGCAAGAGAGTCAATGAGGAG & 99 & 0.95 \\
\hline & & R: CCGGTTCCATAGGCAAACT & & \\
\hline \multirow[t]{2}{*}{ TNFAIP3 } & Tumor necrosis factor, alpha-induced & F: CCCAGCTTTCTCTCATGGAC & 113 & 0.90 \\
\hline & protein 3 & R: TTGGTTCTTCTGCCGTCTCT & & \\
\hline \multicolumn{5}{|c|}{ Genes of interest not showing significant difference between groups } \\
\hline \multirow[t]{2}{*}{ APOA1 } & Apolipoprotein A-I & F: GTTCTGGGACAACCTGGAAA & 86 & 0.81 \\
\hline & & R: GCTGCACCTTCTTCTTCACC & & \\
\hline \multirow[t]{2}{*}{ C3 } & Complement component 3 & F: ATCAAATCAGGCTCCGATGA & 76 & 0.87 \\
\hline & & R: GGGCTTCTCTGCATTTGATG & & \\
\hline \multirow[t]{2}{*}{ CD14 } & CD14 molecule & F:GGGTTCCTGCTCAGATTCTG & 164 & 0.83 \\
\hline & & R: CCCACGACACATTACGGAGT & & \\
\hline \multirow[t]{2}{*}{ CLDN3 } & Claudin 3 & F: ATCGGCAGCAGCATTATCAC & 94 & 0.87 \\
\hline & & R: ACACTTTGCACTGCATCTGG & & \\
\hline \multirow[t]{2}{*}{ CXCL10 } & Chemokine (C-X-C motif) ligand 10 & F: CCCACATGTTGAGATCATTGC & 141 & 0.82 \\
\hline & & R: GCTTCTCTCTGTGTTCGAGGA & & \\
\hline \multirow[t]{2}{*}{$D E F B 1$} & Defensin, beta 1 & F: ACCTGTGCCAGGTCTACTAAAAA & 109 & 0.90 \\
\hline & & R: GGTGCCGATCTGTTTCATCT & & \\
\hline \multirow{2}{*}{$D E F B 4 A(D E F B 2)$} & Defensin, beta 4A & F: CAGGATTGAAGGGACCTGTT & 99 & 0.83 \\
\hline & & R: CTTCACTTGGCCTGTGTGTC & & \\
\hline \multirow{2}{*}{ HPRT1 } & Hypoxanthine phosphoribosyl-transferase & F: ACACTGGCAAAACAATGCAA & 71 & 0.88 \\
\hline & 1 & R: TGCAACCTTGACCATCTTTG & & \\
\hline \multirow[t]{2}{*}{ NFKB1 } & Nuclear factor of kappa light polypeptide & F: CTCGCACAAGGAGACATGAA & 97 & 0.88 \\
\hline & gene enhancer in B-cells 1 & R: GGGTAGCCCAGTTTTTGTCA & & \\
\hline \multirow[t]{2}{*}{ IL18 } & Interleukin 18 & F: CTGCTGAACCGGAAGACAAT & 100 & 0.86 \\
\hline & & R: TCCGATTCCAGGTCTTCATC & & \\
\hline IL6 & Interleukin 6 & F: TGGGTTCAATCAGGAGACCT & 116 & 085 \\
\hline & & R: CAGCCTCGACATTTCCCTTA & & \\
\hline MUC1 & Mucin 1 & F: GGATTTCTGAATTGTTTTTGCAG & 116 & 0.81 \\
\hline & & R: ACTGTCTTGGAAGGCCAGAA & & \\
\hline OCLN & Occludin & F: CGGTGAGAAGATTGGCTGAT & 100 & 0.85 \\
\hline & & R: TTTCAAAAGGCCTGGATGAC & & \\
\hline PAFAH1B1 & Platelet-activating factor acetylhydrolase & F: GCAAACTGGCTACTGTGTGAAG & 113 & 0.83 \\
\hline & $1 \mathrm{~b}$, regulatory subunit 1 & R: GCACAGTCTGGTCATTGGAA & & \\
\hline TGFB1 & Transforming growth factor, beta 1 & F: GCAAGGTCCTGGCTCTGTA & 97 & 0.81 \\
\hline & & R: TAGTACACGATGGGCAGTGG & & \\
\hline TLR4 & Toll-like receptor 4 & F: TTTCCACAAAAGTCGGAAGG & 145 & 0.81 \\
\hline & & R: CAACTTCTGCAGGACGATGA & & \\
\hline
\end{tabular}

